Proceeding ICOGISS 2019

Page 267-274. ISBN: 978-602-6 988-75-1

Web Jurnal Online: jurnal.unmuhjember.ac.id

By: Devi Abdurrahman Nawawi

Regional Disaster Management (Handling Policy In Wonosobo District 2014-2017)

\title{
REGIONAL DISASTER MANAGEMENT (HANDLING POLICY IN WONOSOBO DISTRICT 2014-2017)
}

\author{
Devi Abdurrahman Nawawi \\ (Devcakranegara@Gmail.Com) \\ (Master of Governmental Science in STPMD"APMD" Yogyakarta). \\ (Doctoral student of Doctoral Program in Political Science of Muhammadiyah \\ University of Yogyakarta).
}

\begin{abstract}
Disaster management in Wonosobo Regency is still in the stage of Rehabilitation and Reconstruction, and continues to process to repair disasters that are proactive, preventive, prevent early recovery of disaster so that it improves in regional development planning. The purpose of this study was to discuss how the regional disaster management policies carried out by (BPBD) of Wonosobo Regency, in good governance, develop performance improvement programs, and plan progress management, and organizational governance in terms of pre-post, post-service quality this, discussing changes to the Regional Disaster Management governance regulations, fast, systematic, directed, and complete in the real action of natural disaster management, as well as the factors that support and become obstacles to the disaster management policy of the Regional Disaster Management Agency (BPBD) in 2014- 2017. This study uses descriptive methods using qualitative research, namely research that is more directed at disclosing the problem or the results presented and revealing the facts. to consider the phenomenon of what is experienced by the subject of research. The technique of collecting data used is: 1) Observations from field observations, 2) Interviews with the number of informants, and 3) Documentation. The data analysis technique in this study is interactive analysis. The results of the study indicate that: Disaster Management has not been implemented perfectly, there are still limited Human Resources who understand and understand disaster management, not yet integrated and standardized data / reporting systems and new information in Wonosobo Regency. (Regional Spatial Planning and Environmental Studies) the lack of BPBD budget support in Wonosobo Regency, has not facilitated the BPBD building which functions to save logistics and emergency equipment (the BPBD office in Wonosobo Regency is still one location with the Office of Public Works and Regional Planning and environmental research). The limited mobility of logistics disaster management facilities and infrastructure, to meet the needs of affected communities not complete and complete. Not yet facilitated disaster resilient villages in all disaster-prone villages of Wonosobo Regency. Inadequate rehabilitation and implementation efforts in the aftermath of the disaster, the maximum participation of the community and business community in the implementation of cross-sector and cross-regional disaster management in Wonosobo district. The most priority future challenge is to synergize budget control legislation with regional development planning planning regulations, while new development alternatives are built based on analysis of supporting factors, future challenges and the study of competent technical research.
\end{abstract}

Keywords: Handling Policy, Disaster Management, BPBD. 
Proceeding ICOGISS 2019

Page 267-274. ISBN: 978-602-6 988-75-1

Web Jurnal Online: jurnal.unmuhjember.ac.id

By: Devi Abdurrahman Nawawi

Regional Disaster Management (Handling Policy In Wonosobo District 2014-2017)

\section{INTRODUCTION}

According to the disaster prone district Wonosobo issued by BNPB high category has the potential natural disaster landslides which is in the highest in Central of Java. 5 The district Wonosobo, disasters data recorded between 2006-2010 542 cases, landslides occurred of the total number of rp.16,694, billion loss the intensity of the landslides that cannot be separated from geography district wonosobo located at the foot of the mountain, cleft as many as 54.641 hectares or 56,37 percent of the area in wonosobo was in the area between 15-40 percent at addition to the landslides daily disasters that take place is, fire between 2006-2010 happened 187 a house fire which had caused losses to reach rp.6,8, billion while other disaster who was often happens is that the wind lisus related to the condition of the wonosobo in. height. Regional Secretary of the Wonosobo Regency, Drs, Eko Wibowo, Sutrisno MM reveals that: "a matter of temporary loss due to natural disasters, flood landslide in 116 points in 37 Villages scattered in 13 Subdistricts after rain nearly two days 11-12 December 2014. about Rp 13.7 billion in damage to houses, among others, 116 damaged, roads and bridges. (http://www.solopos.com. 13 December 2014, accessed October 16, 2017. 21.00 o'clock GMT). The level of risk of each type of disaster that could potentially in Wonosobo Regency retrieved based on the combined level of capacity and the level of losses, the result of disaster risk level can be seen from the following table.

Table 1.

Disaster Risk Level of Wonosobo Regency.

\begin{tabular}{|c|c|c|}
\hline No & Type of Disaster & Level of Disaster Risk \\
\hline 1. & Floods & High \\
\hline 2. & Earthquakes & Medium \\
\hline 3. & Forest and Land Fires & High \\
\hline 4. & Drought & medium \\
\hline 5. & Epidemics and Outbreaks of Diseases & Medium \\
\hline 6. & volcanic eruptions & Medium \\
\hline 7. & Extreme Weather & Medium \\
\hline 8. & Landslides & Very High \\
\hline
\end{tabular}

Source: 2014 Wonosobo District BPBD Disaster Recap.

Currently the Wonosobo Regency Government is constrained by limited resources and within a period of 3 (three) years since the formation of the relatively new BPBD so that the domain of experts has not been implemented optimally. This is related to the lack of budget, lack of skilled human resources limited facilities and equipment, lack of other technical aspects. In more detailed forms of cross-sectoral collaboration with several DPOs and other Government agencies involved in disaster management are explained as follows: 1. Cooperation in preparing contingency plans involving several DPOs, related. 2. Climatology and Geophysics Meteorology Agency (BMKG) Karangwates and the Center for Volcanology of Geological Disaster Mitigation (PVMBG) Bandung routinely and periodically send bulletin data and facilitate training activities on volcanic land mitigation movements in 2014. Other institutions involved are the Indonesian Red Cross (PVMBG) Bandung routinely and periodically send bulletin data and facilitate training activities on volcanic land mitigation movements in 2014. PMI), NGOs, Disaster Preparedness Youth (TAGANA), Scouts, 
Proceeding ICOGISS 2019

Page 267-274. ISBN: 978-602-6 988-75-1

Web Jurnal Online: jurnal.unmuhjember.ac.id

By: Devi Abdurrahman Nawawi

Regional Disaster Management (Handling Policy In Wonosobo District 2014-2017)

Indonesian Radio Amateur Organizations (ORARI), Indonesian Inter-Population Radio (RAPI), State-Owned and Private Enterprises.

1. The Regional Disaster Management Agency in cooperation with the Department of Education and Sports (DIKPORA) of Central Java Province held a joint training of 500 Students from elementary, junior high, and high school levels in SMA Mojotengah as an embodiment of the "Disaster Preparedness School" also attended by teacher representatives from 16 schools throughout - Wonosobo. (Wonosobo Ekspres 11/22/2014), (Http: // wonosobo ekspress.com, accessed Monday 30 October 2017 At 10:30 WIB).

2. Volunteer training in disaster mitigation such as the clean river launch program to anticipate the overflow of floods and landslides initiated by BPBD, LINMAS, Camat and Village Heads of Kalikajar Subdistrict in Maduretno Village. (Wonosobo Ekspres 18/10/2017.

http //. Wonosobo ekspress.com, accessed Monday 30

October 2017. At 10:40 WIB).

\section{DISCUSSION}

The paradigm of disaster management in Indonesia is still an emergency response so that it causes enormous losses and damage so it is necessary to need a proactive, preventive response within the framework of disaster risk reduction so that it can be integrated in development planning. Whereas the disaster management process has been carried out even though there is one stage that has not been maximized, namely the identification of disaster risk, which has been carried out by mapping the disaster-prone areas / regions. The most priority future challenges are synergizing disaster management regulations with development planning regulations and the integration of disaster risk reduction to reduce the adverse impacts that arise. (Ahdi: Journal of Reformation Vol. 5 No.1, 2015).

The Regional Disaster Management Agency of Wonosobo Regency has made various efforts to carry out disaster reduction for the 2015-2016 period, including

\section{Prevention and Preparedness.}

The goals and objectives that have been achieved are to increase prevention, preparedness and disaster risk reduction efforts. main activities carried out include:

a. Monitoring, data collection and dissemination of information on potential natural disasters through the installation of banners / banners / early warning signposts.

b. Preparation of a Landslide Disaster Contingency Plan.

c. Compilation of Regent Regulations (Perbup) concerning Wonosobo District Disaster Management Plan along with Action plans

d. The disaster risk reduction coordination meeting is carried out through coordination meetings with stakeholders.

e. Workshop preparation of assessment report on resilience and regional capacity for resilience in the face of disasters.

f. Pick up emergency alert for landslides, floods and strong winds followed by TNI, Polri, BPBD and Volunteers.

g. Disaster management training is followed by the community, officials and disaster management volunteers. 


\section{Emergency Management.}

Objectives and objectives: Increased rescue and evacuation of disaster victims, handling refugees and restoring vital facilities and infrastructure for community activities. The main activities carried out include.

a. Operational Control Center Command Post (Pusdalops) as the center for controlling.

b. emergency response operations for handling disaster events, the post is carried out by the picket system for 24 hours / 7 days to strengthen communication, coordination, consolidation and reports of disaster events.

c. Deployment of SAR team members / volunteers in disaster management

d. Logistics Procurement for disaster victims.

e. Establishment and briefing of disaster emergency response team (TRC)

f. Post and rehearsal rehearsals for disaster emergency handling are carried out every year.

g. Dropping clean water.

h. Providing logistical assistance to disaster victims through logistics from BPBD, Provincial

i. BPBD and from BNPB.

\section{Rehabilitation and Reconstruction Objectives}

a. Increased Post-Disaster Rehabilitation and Reconstruction Activities through better Improvement, Recovery, Improvement and Development. The main activities carried out include.

a. Preparation of Damage and Losses Assessment (DaLA), Human Recovery Needs Assessment (HRNA), and Jitu Pasna for making action plans.

b. Post-disaster Rehabilitation and Reconstruction with activities to repair vital facilities and infrastructure due to disasters through unexpected expenditure. Results of Interviews with researchers ( Drs. Eco Sutrisno Wibowo.MM Secretary Wonosobo Regency today Tuesday 06 April 2018) that in handling disaster relief is inseparable from the role of BPBD as the Leading Sectoryang not be separated with the Organization of the device area (OPD) other technical who was instrumental in handling such disasters, authority/authorities of the BPBD spelled out as follows:

1. Disaster Relief Coordination is carried out through with government agencies as well as centre of the region, both the Agency's efforts, international institutions and or/the party deemed necessary at the stage prabencana and post disaster. the coordination of the implementation of one of these is the setting of policies aligned with development planning.

2. In conditions of emergency BPBD run Command functions in the framework of the handling of emergency in the affected region through the deployment of human resources, equipment, and logistics from BPBD and related institutions, the national army and Indonesia State police of the Republic of Indonesia as well as other measures needed in order handling emergency disaster.

3. The functions of the latter is the role of Executor, is associated with post-natal disaster that is implemented in a coordinated and integrated with government agencies as well as Centre good areas, with attention to conducting policy countermeasures disasters, development policy, as well as in accordance with the provisions of the legislation. (Interview with. Eko Sutrisno Wibowo). 


\section{a. Inhibiting factors:}

1. Differences in position in the organizational structure.

2. The BPBD organization in Wonosobo Regency is still in the organizational structure B (echelon III) because indeed the BPBD organization is a new organization. This makes it difficult for the level of cross-agency or agency coordination for echelon II. Differences in position in the organizational structure (echelon II and echelon III) will cause coordination between agencies / agencies to be long because it takes a long time also in the cooperation process so that the development process also becomes hampered.

3. Limited facilities and infrastructure.

4. Because BPBD is a formation of a new organization so that the completeness of tools and facilities in training and education efforts is very minimal.

5. Heterogeneity from employee agencies.

6. The employee differences here are employees who come from various other agencies such as the Public Works Office, the Indonesian Red Cross (PMI), the Keshatan Service, SAR,

7. Disaster Response (Tagana), Indonesian Inter-Population Radio (RAPI), Indonesian Amateur Radio Organization (ORARI).

\section{b. Supporting factors.}

1. High employee motivation.

2. The motivation of employees at BPBD in Wonosobo Regency is high on efforts to develop personalities in disaster management efforts on reducing disaster risk reduction. This can be seen from the absence of the list of attendees of BPBD staff in Wonosobo Regency and the Official Travel Administration Letter (SPPD) of BPBD staff in Wonosobo Regency.

3. Government policy support.

4. The government also assists in the form of budget originating from the APBN and APBD of Wonosobo Regency, as a form of interest in the need to handle disasters and disaster risk reduction exercises. The process of providing funds by the government is carried out in the manner of submitting a Budget Implementation Document (DPA) that can be approved or not.

5. Public and private participation.

6. In the process of human resource development it is also supported by the participation of the community and private sector as a form of community selfreliance which includes energy, thought / ideas, material, and money as an effort to manage disasters in reducing disaster risk.

\section{Problem Formulation.}

Based on the description of the background of the problem, the researcher can formulate the problems in this study, namely .

1. What is the disaster management policy of the Wonosobo District Regional Disaster Management Agency (BPBD) in disaster management for 2014-2017. 
Proceeding ICOGISS 2019

Page 267-274. ISBN: 978-602-6 988-75-1

Web Jurnal Online: jurnal.unmuhjember.ac.id

By: Devi Abdurrahman Nawawi

Regional Disaster Management (Handling Policy In Wonosobo District 2014-2017)

2. What factors support and become an obstacle to the disaster management policy of the

Wonosobo District Regional Disaster Management Agency (BPBD) in 20142017.

\section{Research Objectives.}

The objectives to be achieved in this study are:

1. To describe the Regional Disaster Management PolicY (BPBD) 2014-2017.

2. To describe the supporting factors and obstacles to the Handling Policy Regional Disaster Management (BPBD) 2014-2017.

\section{E. Theoretical / Conceptual Framework.}

I. Disaster Management and Management.

2. Theory of Organizational Performance Evaluation.

3. Capacity Building in disaster management in Wonosobo.

\section{CONCLUSIONS AND SUGGESTIONS}

\section{A. Conclusions}

The role of all parties in the handling of the disaster will be optimal if coordinated and integrated well, as the number of parties involved in a significant way will give you a real influence when the disaster happened and post disaster occurs. Therefore, local governments need to establish good cooperation with all, both private (business world) and the community. Good cooperation of the third pillar of the implementation of the a good layout good governance also Government the entire stakeholders problems encountered in field research and the need to immediately be thoroughly addressed, among others, are:

1. Still limited human resources know and understand about the handling of the disaster.

2. Have not been integrated and mechanisms standart/reporting system information data disaster and lack of budget support BPBD Wonosobo Regency.

3. Not yet facilities BPBD building which served for storage logistics and equipment to disaster (Researchers see officer BPBD Wonosobo Regency still become one with the Office of public works and Spatial Locality DPU-TRW) and still the limited mobility of equipment and means of disaster relief, the availability of logistics, in order to meet the basic needs of disaster affected communities in Wonosobo Regency.

4. full guidelines and the document has not been conducting disaster relief (the formation of the village of disaster resilient across the disaster-prone village of Wonosobo Regency, not facilities and human resources competence countermeasures disaster, not to the efforts of post reconstruction and rehabilitation and not to the role of the community and the business world in organizing disaster relief in Wonosobo Regency.

5. Not yet Synchronization the Organization of disaster relief of cross-sector and cross-region. Disaster relief policy was drawn up on the basis of Wonosobo Regency regulatory, institutional and public planning for each phase of a disaster, a disaster phase consists of the phases of prevention, mitigation, preparedness, response, rehabilitation and emergency reconstruction. 
Proceeding ICOGISS 2019

Page 267-274. ISBN: 978-602-6 988-75-1

Web Jurnal Online: jurnal.unmuhjember.ac.id

By: Devi Abdurrahman Nawawi

Regional Disaster Management (Handling Policy In Wonosobo District 2014-2017)

\section{B. Suggestions}

Regional disaster mitigation model empirically it becomes very important to apply the various issues of development as a real manifestation of the Government's responsibility in the face of the various needs of the community that put forward community-based planning, Community Base Development (CBD) with the involvement of more players-offender development (stake holders) in creating Good Government in accordance with the provisions of the new paradigm, which in turn will able to create wisdom that the impact seeps down (trickle down effect) so that a small community on the alignments actually noteworthy in the context of the handling of the disaster response community and tough toward disaster.

1. Recruit a competent human resource experts as well as understand and understand about the handling of the disaster.

2. Integrity, transparency and accountability in the standard mechanisms/reporting system data disaster information and funding/budget BPBD Wonosobo Regency.

3. for performance and handling countermeasures can be run with maximum then Adequate infrastructure (building a new BPBD) serves for storage Logistics and equipment to disaster as well as a means of mobility equipment and countermeasures disaster logistics, availability, to meet the basic needs of affected communities disaster in Wonosobo Regency.

4. Inventory comprehensively with the full guidelines and documents of organizing disaster relief (the formation of the village of disaster resilient across the disaster-prone village of Wonosobo Regency, terfasilitasi and resource competence the human field of disaster relief, rehabilitation and reconstruction efforts to maximize the post, plays an active role invites all walks of life, the business world as well as component resources at every level levels to participate in organizing disaster relief in Wonosobo Regency.

5. Synchronization of organizing disaster relief and cross-cross-sector and Region, (Sub,village apparatus) command BPBD as the leading sector. 
Proceeding ICOGISS 2019

Page 267-274. ISBN: 978-602-6 988-75-1

Web Jurnal Online: jurnal.unmuhjember.ac.id

By: Devi Abdurrahman Nawawi

Regional Disaster Management (Handling Policy In Wonosobo District 2014-2017)

\section{REFERENCE}

Undang - undang Nomor 24 Tahun 2007 tentang penanggulangan bencana.

Pemerintah Kabupaten Wonosobo, Rencana Pembangunan Jangka Panjang Menengah Daerah (RPJMD) Kabupaten Wonosobo 2010 - 2015.

-Peraturan BupatiWonosobo Nomor 33 Tahun 2010, tentang penanganan bencana daerah.

------------Peraturan Daerah No.3 Tahun 2014, tentang Penanggulangan Bencana Daerah.

Wonosobo District., BPBD Disaster Recap. 2014. Wonosobo Ekspres 11/22/2014, http: // wonosobo ekspress.com, accessed Monday,

30 October 2017 At 10:30 WIB.

Wonosobo Ekspres 18/10/2017, http// Wonosobo ekspress.com, accessed Monday, 30 October 2017. At 10:40 WIB.

Ahdi, Journal of Reformation Vol. 5 No.1, 2015. 